L. Sakovych ${ }^{1}$, Ye. Ryzhov ${ }^{2}$, A. Soboliev ${ }^{1}$

${ }^{1}$ Institute of Special Communication and Information Security of the National Technical

University of Ukraine "Igor Sikorsky Kyiv Polytechnic Institute", Kyiv

${ }^{2}$ Hetman Petro Sahaidachnyi National Army Academy, Lviv

\title{
METHOD OF TIME DISTRIBUTION FOR REPAIR OF RADIO ELECTRONIC MEANS WITH MULTIPLE DEFECTS
}

The article proposes a method of redistribution of time between stages of diagnostics and complete elimination of defects of radio-electronic means in the conditions of the repairing service. The method minimizes the average recovery time in the process of elimination of multiple defects which result from accidental or combat damage. It consists in a comprehensive consideration of the components of the repair process after preliminary identification of defects at the location of damage and in the estimation of the expected multiplicity of defects.

A block diagram of the algorithm for solving of this problem is proposed. The algorithm differs from the known analogs by the account for the probability of correct diagnosis and the metrological reliability of the used measuring equipment.

The application of the method at given conditions allows us to quantify the time of implementation of each stage of recovery and to reasonably recommend a redistribution of efforts to minimize the average recovery time of electronic devices with multiple defects.

An example of the application of method, illustrating the influence of managed variables on the efficiency of the method, is presented. The use of the obtained results allows one to increase the capability of military repairing service in the recovery of equipment with weak and medium combat damages, either in the field conditions, or at the points of maintenance and repair service. The proposed method is recommended for implementation in the software for maintenance of the REMs of modular type.

Keywords: radio-electronic means, multiple defects, diagnosis, restoration of working capacity.

\section{Statement of the problem, analysis of recent research and publications}

Upon accidental or combat damaging in the field conditions radio-electronic means (REM) usually have multiple (numerous) defects. In such a case the recovery is performed in several stages: first, at the place of damage the repairing crews performs preliminary inspection to determine the extent of damage; at the second stage, a repairing specialist completes the isolation and description of faults and eliminates those which are well evident; at the third, stage using measuring instruments (MI) and diagnostic software one eliminates the hidden defects and restores the unit, which is under repair, to the working state. These Authors consider methods for recovering the REMs, assessing their real technical state, developing effective diagnostic support for the current repair. There are several peculiarities of the recovery of REM with multiple defects which have to be studied and which affect the effective work of the repair team in the elimination of emergency and combat damage, especially in the field conditions.

In the available literature [1-8] the directions of the improvement of the efficiency of current repair of REM is considered in the presence of a single defect. However, when repairing REMs with multiple defects in conditions of distanced repair and supply bases, the average recovery time can be minimized by improving the efficiency of defecting and diagnosis. For this reason, the determination of the real technical state of REM in the presence of multiple defects is an important scientific task. Approaches to its solution are presented in [9-14], however they do not take into account the current achievements of technical diagnostics in terms of reliability of diagnosis [15-17] and metrology [18], which allow to take into account the metrological reliability of the measuring instrument (MI). In this paper we fill this gap.

The purpose of the article is to formalize the process of time distribution for its minimization in the course of stages of the recovery of REMs with multiple defects for the assessment of the quality of metrological and diagnostic support.

\section{The main material}

The problem is solved on the basis of taking into account the results of the preliminary identification of defects, following the method [14], using an external tester to determine the degree of damage in the REM

$$
S=Q / L,
$$

where $Q$ is the multiplicity of defects from the total number of elements $L$. 
In this case, the objective function takes the form

$$
T_{B}(X)=\min T_{B}\left(X^{*}\right) ; X^{*} \in \Delta,
$$

where $T_{B}$ is the average recovery time of the REM, $X$ are the parameters of the repair system, $X^{*}$ are their given values at the solving of the problem, $\Delta$ is the set of allowable parameter values:

$$
X=\left\{L, S, t_{i}, p, P, K\right\},
$$

where $t_{i}$ is working time for inspections and troubleshooting, $p$ is the probability of a correct assessment of the result of the inspection, $P$ is the metrological reliability of the MI, $K$ is the average number of inspections by the algorithm of diagnosis.

Then the effectiveness of the method is measured by the index

$$
0 \leq \eta=\frac{T_{B}-T_{B}{ }^{\prime}}{T_{B}{ }^{\prime}} \leq 1,
$$

where $T_{B}{ }^{\prime}$ is the reduced mean recovery time of REM with multiple defects by known methods.

It is shown in [9-14], that the time of complete detection and elimination of each subsequent fault increases in comparison with the previous value. In this case, for the approximation one uses the geometric progression with the common ratio $g>1$, then the time of complete procedure of the fault identification (CPFI) can be quantified by the expression

$$
T_{1}=\frac{t_{1}\left(g Q_{0}-1\right)}{g-1},
$$

where $t_{1}$ is the time of detection of the first fault and its repair, $Q_{0}$ is the total number of faults detected at the CPFI. The CPFI is performed by a qualified specialist via the external inspection of all structural units (blocks, typical replacement elements) of the REM without employment of special software. Usually one uses simple MIs, for example, a tester for detection of breakages and short-circuits. After the CPFI, the REM contains $Q-Q_{0}$ hidden faults, for identification of which one needs the diagnostic support in the form of the diagnostic software and special MIs. In [9-14] it is proposed to divide the inspected REM into $Q-Q_{0}$ parts with uniform distribution of faults, if the PCFI is performed by a single specialist. Then after the elimination of all the faults identified in the previous part of the REM, the specialist starts the diagnosis of the next part. The total number of inspections at the search of hidden defects will be

$$
K=\left(2+\log _{2} \frac{L}{Q-Q_{0}}\right)\left(Q-Q_{0}\right)+1,
$$

and the average diagnosis time will be equal

$$
T_{2}=\frac{K \cdot t+t_{y}\left(Q-Q_{0}\right)}{p^{K} \cdot P},
$$

where $t_{y}$ is the average troubleshooting time.

The total recovery time of the RES will be

$$
T_{B}=T_{1}+T_{2} \text {. }
$$

Obviously, the more faults will be found at the PCFI, the less time will be needed for search of the hidden defects at diagnostics. In other words, at the increase of $Q_{0}$, the time $T_{1}$ of the identification of faults increases and the time of diagnosis decreases. Therefore their sum will show a minimum (Fig. 1) at some value $Q_{0}$.

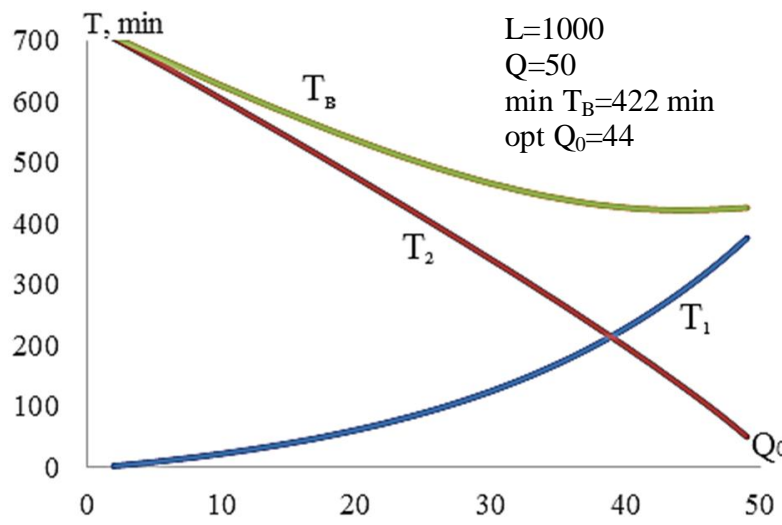

Fig. 1. The time ( $\left.T_{1}\right)$ needed for the CPFI, the time of

diagnosis $\left(T_{2}\right)$ and average recovery time $T_{B}$ as a function of the quality of PCFI ( $\left.Q_{0}\right)$

An attempt to find a minimum of the function $T_{B}\left(Q_{0}\right)$ leads to a transcendental equation for which the explicit solution is not known. Therefore, the minimum value $T_{B}^{\min }$ should be calculated numerically using the algorithm depicted by the diagram, shown in Fig. 2, where $D$ is the fraction of the PCFI time in the total recovery time of REM.

The correction of the average recovery time, taking into account the metrological reliability of the MI and the probability of correct diagnosis in percentage is of the form

$$
\begin{gathered}
\eta=\frac{\Delta T_{B}}{T_{B}{ }^{\prime}} ; \\
\Delta T_{B}=\frac{\left(K t+t_{y}\left(Q-Q_{0}\right)\right)\left(1-p^{K} P\right)}{p^{K} \cdot P} ; \\
\eta=\frac{\left(1-p^{K} P\right)\left(K t+t_{y}\left(Q-Q_{0}\right)\right)(g-1)}{p^{K} P \cdot\left(t_{1} \cdot\left(g^{Q_{0}}-1\right)\right)+(g-1)\left(K t+t_{y}\left(Q-Q_{0}\right)\right)} 100 \% .
\end{gathered}
$$




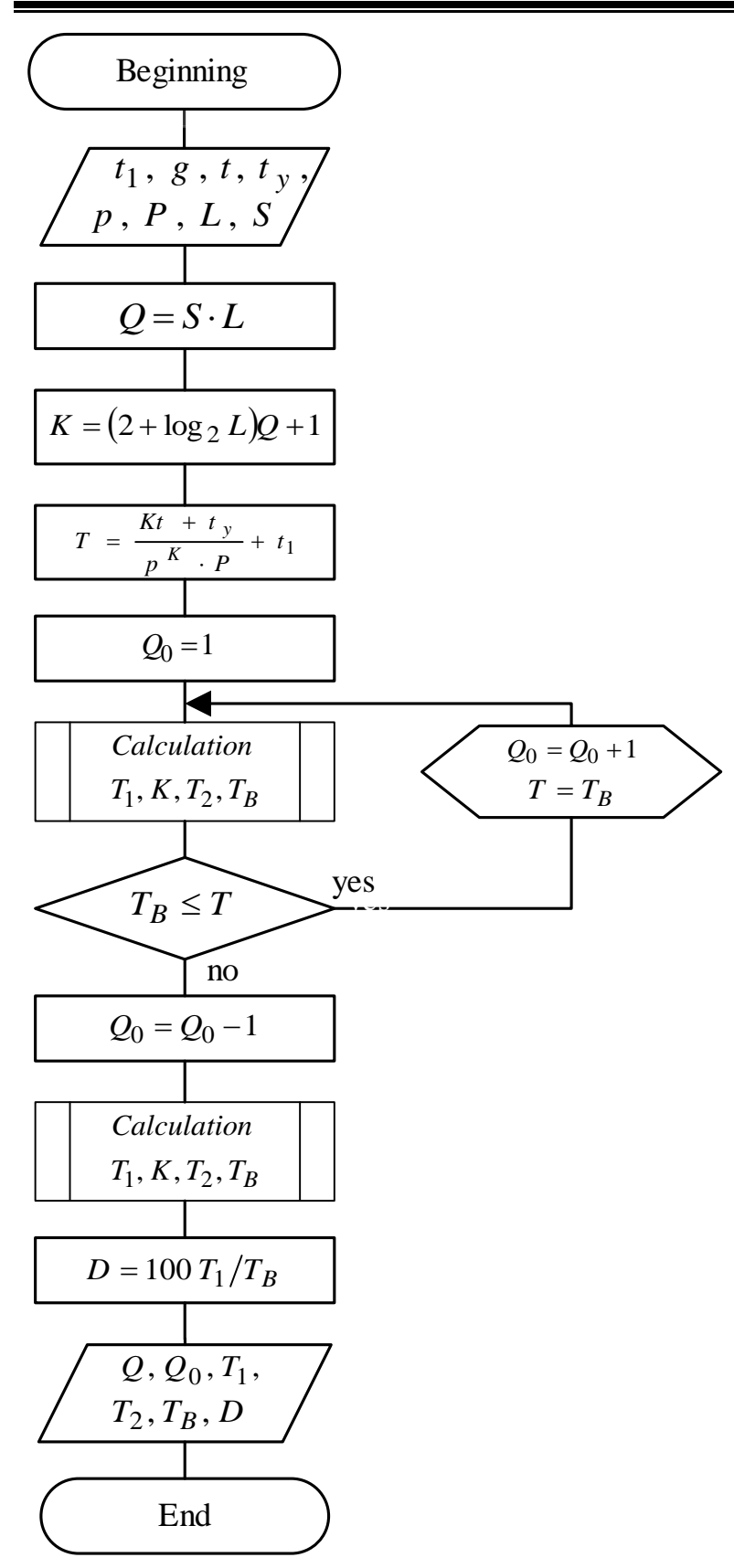

Fig. 2. Flowchart of the algorithm for determination of the minimum recovery time and the optimal time of CPFI

Following the algorithm, shown in Fig. 2, we have developed a computer program and performed a simulation of the process of recovery of the REM with the following initial data: $L=1000 ; \quad t_{1}=2 \mathrm{~min}$; $g=1,05 ; \quad t=2 \min . ; \quad t_{y}=3 \min . ; \quad p=0,9992$; $P=0,978 ; S=0,05$.

The analysis of the obtained results allows us to draw the following conclusions:

- improvement of the quality of metrological support $p$ has a significant impact on value $T_{B}$ (increase in value $p$ from 0.9 to 0.999 reduces the value $T_{B}$ by four times) (fig. 3);
- increase of metrological reliability $P$ of the MI leads to a proportional decrease in the minimal value $T_{B}^{\min }$ of $T_{B}$ (fig. 4 );

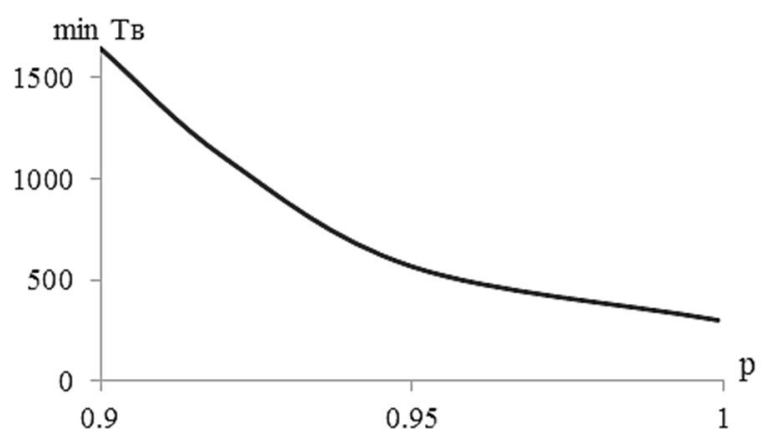

Fig. 3. Dependence of the minimal average recovery time on the probability of a correct evaluation of the result of the test

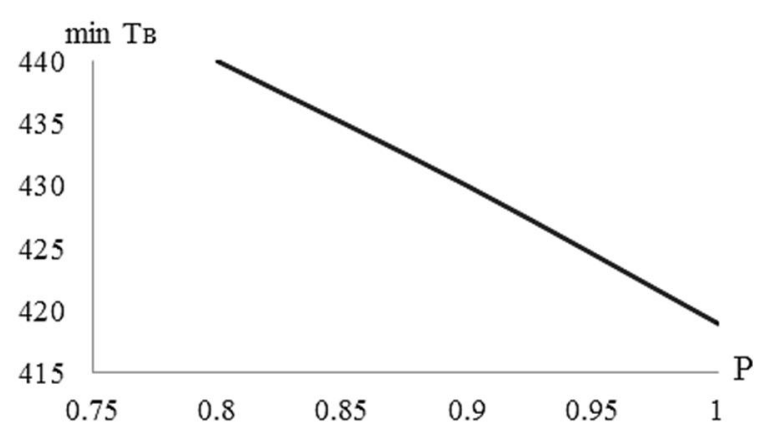

Fig. 4. Dependence of the minimal average recovery time on the metrological reliability of measuring instruments

- the minimal value $T_{B}^{\min }$ grows linearly with the degree of damage in the REM (Fig. 5);

- the fraction of time of the PCFI of the REM increases with the increase of the damage of the RES (Fig. 6).

Our estimation shows that for $L=1000$ and $S=0.05$, one has

$$
\begin{gathered}
\min T_{B}(p=0,99 ; P=0,95)=447 \min . ; \\
\min T_{B}(p=1 ; P=1)=410 \min . ; \\
\eta=9 \% .
\end{gathered}
$$

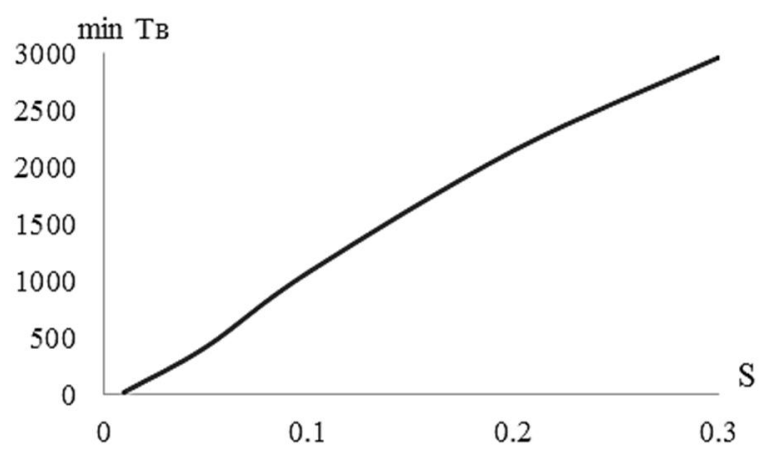

Fig. 5. Dependence of the minimal average recovery time on the degree of damage to the product 


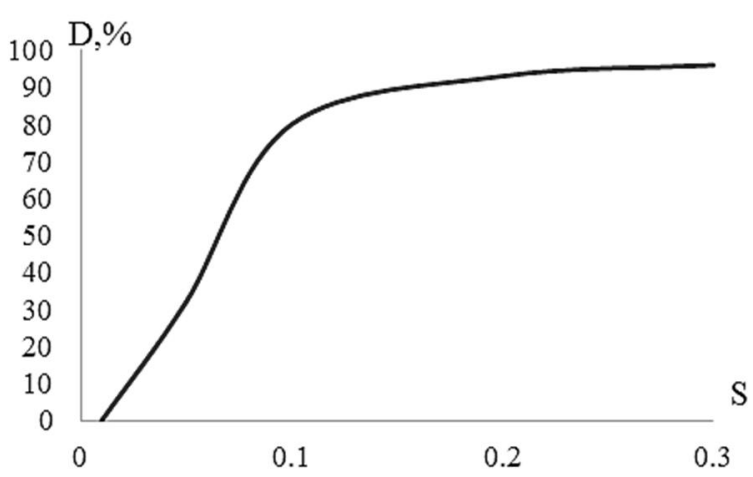

Fig. 6. Dependence of the relative time of PCFI on the degree of damage of the REM

Our estimation shows that for $L=1000$ and $S=0.05$, one has

$$
\begin{gathered}
\min T_{B}(p=0,99 ; P=0,95)=447 \mathrm{~min} . ; \\
\min T_{B}(p=1 ; P=1)=410 \mathrm{~min} . \\
\eta=9 \% .
\end{gathered}
$$

Thus, the account for the quality of metrological support in this case allows one to correct the average recovery time by $9 \%$ in comparison with the previously known methods [9-14].

\section{Conclusions}

1. The proposed method is intended to determine the time of complete procedure of the fault identification (CPFI) of the REM in the elimination of emergency and combat damage of various degrees in order to minimize the average recovery time.

2. The scientific novelty of the obtained results consists in the account for the quality of metrological maintenance of repair, which was not done in the previously known methods.

3. The effect of the method consists in the correction of the calculated value of the minimal average recovery time of the REM with multiple defects, which allows one to plan the capacity of the repairing office.

4. The obtained results can be used for the development of the software for maintenance of the REMs of modular type.

5. Further studies are needed to clarify the functional dependence of the time of PCFI on the degree of damage in the REM and on the qualification of specialists of the repairing office.

\section{References}

1. Fundamentals of the theory of restoration of operational properties of technical systems / M.A. Kovtunenko, V.V. Shishanov, V.V. Zubarev. - Kiev: Books of the NAU type, 2007. $-296 p$.
2. Lenkov S.V. Formalization of process of carrying out of repair of components of radio-electronic equipment / S.V. Lenkov, V.V. Zubarev, R.M. Salimov, V.A. Protsenko // Bulletin of Cherkasy State Technological University. Cherkasy: 2009. - P. 20-22.

3. Yanliang Li. Application and improvement study on FMEA in the process of military equipment maintenance / Yanliang Li, Rui Kang, Lin Ma, Lei Li // 9th International Conference on Reliability, Maintainability and Safety, 12-15 June 2011, Guiyang, China: Proc. -IEEE, 2011. - Vol. I, II. P. 803-810.

DOI: http://dx.doi.org/10.1109/ICRMS.2011.5979402.

4. Thomson $R$. The benefits of using head mounted displays and wearable computers in a military maintenance environment / Robert Thomson, John Lynn // 2010 International Conference on Education and Management Technology (ICEMT), 2-4 November 2010, Cairo, Egypt: Proc. - IEEE, 2010. - P. 560-564.

DOI: http://dx.doi.org/10.1109/ICEMT.2010.5657592.

5. Qiao Ma. Decision-making model for ranking battlefield damaged equipment repairs based on multi-criteria / Qiao Ma, Guibo Yu, Lijun Cao, Jinhui Zhao, Bing Feng // 2013 International Conference on Quality, Reliability, Risk, Maintenance, and Safety Engineering (QR2MSE), 15-18 July 2013, Emeishan, Sichuan, China: Proc. - IEEE, 2013. - Vol. II. P. 1942-1944.

DOI: http://dx.doi.org/10.1109/QR2MSE.2013.6625959.

6. Haikuan Wang. The application of TOPSIS on sequencing decision-making in equipment battlefield repair / Haikuan Wang, Quan Shi, Fei Xiong, Kan Wang // 2013 International Conference on Quality, Reliability, Risk, Maintenance, and Safety Engineering (QR2MSE), 15-18 July 2013, Emeishan, Sichuan, China: Proc. - IEEE, 2013. - Vol. II. P. 1574-1578.

DOI: http://dx.doi.org/10.1109/QR2MSE.2013.6625876.

7. Chunliang Chen. The key operation ascertaining of armored equipment parts batch-repair progress for quality monitoring based on FCE / Chunliang Chen, Wenhua Shi, Shixin Zhang I/2013 International Conference on Quality, Reliability, Risk, Maintenance, and Safety Engineering (QR2MSE), 15-18 July 2013, Emeishan, Sichuan, China: Proc. IEEE, 2013. - Vol. II. - P. 1542-1545.

DOI: http://dx.doi.org/10.1109/QR2MSE.2013.6625867.

8. Fundamentals of the theory of reliability and operation of radioelectronic systems / V.I. Vasilishin, SV Zhenzhera, OV Chechui, A.P. Glushko. - X.: KhNUPS, 2018. - 268 p.

9. Algorithmization and formalization of the process of fault detection of equipment for information security systems with accidental damage: Coll. sciences. Ave DSSZZI / L. Sakovich, V. Pavlov. - 2004. - Vol. 9. - P. 168-180.

10. Sakovych L.N. Defective technique of communication with emergency damage / L.N. Sakovych, V.P. Pavlov // Communication. - 2004. - № 7. - P. 52-56.

11. Pavlov V.P. Synthesis of Algorithm for Damage Damage Defect Algorithm / V.P. Pavlov, L.M. Sakovych // Communication. - 2007. - № 6. - P. 54-55.

12. Sakovych L.N. Modeling the process of repairing equipment for information security systems with emergency 
damage / L.N. Sakovych, V.P. Pavlov, V.A. Ryzhakov // Legal, regulatory and metrological support of information security systems in Ukraine. No. № 8. - K.: NTUU "KPI". - 20.04. P. 10-19.

13. Sakovich L.N. Algorithmization and formalization of the process of defecting the equipment of information protection systems with emergency damage / L.N. Sakovich, V.P. Pavlov // Legal, regulatory and metrological support of information security systems in Ukraine. No. № 9. - K.: NTUU "KPI". - 2004. - P. 168-180.

14. Sakovich L.M. The technique of preliminary defect of hardware communications with multiple damages in field conditions / L.M. Sakovich, Ye.V. Ryzhov // Bulletin of the National Technical University of Ukraine "Kiev Polytechnic Institute". ADJUSTMENT Series. - 2017. - Vol. 53 (1). - P. 32 38. DOI: http://dx.doi.org/10.20535/1970.53(1).2017.106580.
15. Ksenz S.P. Diagnostics and maintainability of electronic equipment. - M.: Radio and communications, 1989. $248 p$.

16. Ksenz S.P. Theoretical and applied problems of diagnosing communications and automation / S.P. Ksenz, A.A. Volynsky, L.N. Sakovich and others. - L.: HCA, 1990. - 336 p.

17. Ksenz S.P. Fighting diagnostic errors during maintenance and repair of control, communication and navigation systems / S.P. Ksenz, M.I. Poltorzhitsky, S.P. Alekseev, V.V. Mineev. - SPb.: HCA, 2010. - 240 p.

18. Kononov V.B. Fundamentals of Operation of Means of Measuring Equipment for Military Purposes under the conditions of Antiterrorist operation / V.B. Kononov, S.V. Vodolazhko, S.V. Koval, A.M. Naumenko, I.I. Kondrashova. - Kh. KhNUPS, 2017. -288 p.

\title{
Метод розподілу часу при відновленні радіоелектронних засобів з кратними дефектами
}

\author{
Л.М. Сакович, Є.В. Рижов, А.М. Соболєв
}

У статті запропоновано метод перерозподілу часу між етапами повної дефектації та діагностуванням радіоелектронних засобів в умовах ремонтного органа. Метод дозволяє мінімізувати середній час відновлення при усуненні кратних дефектів, отриманих в результаті аварійних або бойових ушкоджень. Він полягає в комплексному розгляді складових прочесу ремонту після попередньої дефектаџії на місиі пошкодження $і$ оиінки прогнозованої кратності дефектів. Зазначено, чим більше дефектів буде виявлено при повній дефектаиії, тим менше часу пошуку прихованих дефектів при діагностуванні: тобто в міру збільшення загальної кількості виявлених дефектів при повній дефектації час дефектаиії збільшується, а час діагностування зменшується.

Розроблено блок-схему алгоритму вирішення зазначеного завдання, щзо відрізняється від відомих урахуванням ймовірності правильної постановки діагнозу та метрологічної надійності засобів вимірюваної техніки, яка використовується.

Застосування методу в конкретних умовах дозволяє кількісно оцінити час реалізації кожного етапу відновлення і обтрунтовано рекомендувати перерозподіл зусиль для мінімізаиії середнього часу відновлення працездатності радіоелектронних засобів з кратними дефектами.

Наведено приклад реалізації методу, де досліджено вплив керованих змінних на його ефективність. Використання отриманих результатів дозволяє підвищити пропускну здатність військових ремонтних органів при відновленні техніки із слабкими і середніми бойовими ушкодженнями, як в польових умовах, так і на пунктах технічного обслуговування і ремонту.

Наукова новизна отриманих результатів полягає в обліку якості метрологічного забезпечення ремонту, чого не робилося в відомих методиках. Ефект від реалізаиї методу полягає в уточненні розрахункового значення мінімуму середнього часу відновлення радіоелектронних засобів з кратними дефектами, щэо дозволяє планувати пропускну здатність ремонтного органа.

Запропонований метод доиільно реалізувати в програмному забезпеченні перспективних апаратних технічного забезпечення модульного типу.

Ключові слова: радіоелектронні засоби, кратні дефекти, дефектація, діагностування, відновлення працездатності.

\section{Метод распределения времени при восстановлении радиоэлектронных средств с кратными дефектами}

\author{
Л.Н. Сакович, Е.В. Рыжов, А.Н. Соболев
}

В статье предложен метод перераспределения времени между этапами полной дефектации и диагностирования радиоэлектронных средств в условиях ремонтного органа. Метод позволяет минимизировать среднее время восстановления при устранении кратных дефектов, полученных в результате аварийных или боевых повреждений. Он заключается в комплексном рассмотрении составляюших процесса ремонта после предварительной дефектации на месте повреждения и оценки прогнозируемой кратности дефектов. Отмечено, чем больше дефектов будет обнаружено при полной дефектации, тем меньше времени поиска скрытых дефектов при диагностировании, то есть по мере увеличения общего количества выявленных дефектов при полной дефектации время дефектации увеличивается, а время диагностирования уменьшается. 
Разработана блок-схема алгоритма решения указанной задачи, отличающегося от известных учётом вероятности правильной постановки диагноза и метрологической надёжности используемых средств измерений.

Применение метода в конкретных условиях позволяет количественно оченить время реализации каждого этапа восстановления и обоснованно рекомендовать перераспределение усилий для минимизации среднего времени восстановления работоспособности радиоэлектронных средств с кратными дефектами.

Приведён пример реализации метода, исследовано влияние управляемых переменных на его эффективность. Использование полученных результатов позволяет повысить пропускную способность войсковых ремонтных органов при восстановлении техники со слабыми и средними боевыми повреждениями, как в полевых условиях, так и на пунктах технического обслуживания и ремонта.

Научная новизна полученных результатов заключается в учете качества метрологического обеспечения ремонта, чего не делалось в известных методиках. Эффект от реализации метода заключается в уточнении расчетного значения минимума среднего времени восстановления радиоэлектронных средств с кратными дефектами, что позволяет планировать пропускную способность ремонтного органа.

Предлагаемый метод иелесообразно реализовать в программном обеспечении перспективных аппаратных технического обеспечения модульного типа.

Ключевые слова: радиоэлектронные средства, кратные дефекты, дефектации, диагностирование, восстановление работоспособности. 